\title{
VALUE RELEVANCE OF RISK MANAGEMENT DISCLOSURE AMONG LISTED DEPOSIT MONEY BANKS IN NIGERIA
}

\author{
Johnson Kolawole OLOWOOKERE \\ Osun State University, Osogbo, Nigeria \\ johnson.olowookere@uniosun.edu.ng \\ Bolarinwa R. FERUKE \\ Osun State University, Osogbo, Nigeria \\ bola.feruke@uniosun.edu.ng
}

\begin{abstract}
This study examined the value relevance of risk management disclosure among listed deposit money banks in Nigeria. The data were collected from 10 listed deposit money banks using purpose sampling and manual content analysis for the period ranging from 2014 to 2018. Descriptive statistics tools of mean, standard deviation together with correlation analysis were used for preliminary analysis while the value relevance of risk management disclosure was estimated using random effect panel regression based on the outcome of the various specification tests. The results were obtained by controlling for book value per share, earning per share, and firm characteristics including the age of the firm, firm size, and leverage. The results obtained revealed that the value of Nigerian listed deposit money banks is positively and significantly affected by the disclosure of risk management. This study, therefore, recommends that managers of the deposit money banks in the country should be concerned with the disclosure of risk management in their annual report to enhance the development of their company's share price which will, in turn, increase the company's value.
\end{abstract}

Keywords: Deposit Money Banks; Firm Value; Risk; Risk Management; Value Relevance DOI: https://doi.org/10.24818/beman/2021.11.4-05

\section{INTRODUCTION}

Risk management disclosure is a very important practice required of corporations in this ever- rapid changing business environment as it affects corporate achievements. The risk management growth is mainly attributed to the growing nature and type of risks corporations face due to the more complexity of the business world (Duru, et al., 2018; Shortreed, et al., 2003). Business can hardly operate without risk, implying that risk is inevitable in any corporate setting. The management of a firm may be classified as risk lover, riskaverse, or risk-neutral depending on the amount of risk the management wishes to take. Theoretical 
evidence suggests that the gains recorded by the firm are highly related positively to the risk-taking level by the firm (Fadun, 2013). Risks basically come from the internal or external business environments and the increase in risks come naturally from financial issues related risks such as exchange rate volatility, interest rate and commodity prices fluctuation (Lombardi et al., 2016). Risks could be credit risk, foreign exchange risk, liquidity risk, interest rate risk, operational risk etc. Thus, the risk is central to firms' strategic decisions, which might be responsible for uncertainty in an organization or embedded in the undertakings of an organization (Elshandidy et al., 2013).Timely disclosure of risk management by a firm is therefore in the best interest of the stakeholders (Elshandidy, 2014).

The strategic nature of the banking sector as highly risky makes the disclosure of risk management critical to the investors and other stakeholders. In particular, investors need information on firm's exposure to risk and the strategies being adopted in managing such risks which will guide them to make rational investment choices (Solomon et al., 2000). It has been argued that failure to disclose relevant information including risk management by banks especially have a number of unintended consequences including information asymmetry and moral hazard problem by an extension (Abdel-Azim \& Abdelmoniem, 2015; Bravo, 2017). The inadequate or non-disclosure of risk management information by the banks has the potential to reduce the prospects of the investors in monitoring and controlling the management risk-taking behaviour with attendant influence on market stability (Bushman, 2016; Duru, et al., 2018). Information asymmetry could however be reduced by providing a report that informs of the bank exposure in transparent manner (Bushman, 2016; Giner \& Mora, 2019). Along the same line, Tadese (2006) suggests that countries characterized with transparent and regulated disclosure are less likely to witness banking crises. By implication, transparency of the financial information could be crucial to the efficacy of the market. Even though the potential of risk management disclosure to drive efficiency has been argued, others are of the view that since disclosure of bank failure to investors reduces their confidence in the entire system, such disclosure may lead to inefficiency in the banking sector and reputational contagion (Abdullah et al., 2012). Evidence suggests that if risks are not properly managed, they can plunge a company into perpetual losses and even liquidation (Bravo, 2017; Nier, 2005; Tadese, 2006). This implies that timely disclosure of risk management may be of significant importance to the value of the firm. In line with that thought, varieties of corporate scandals have been linked with inadequate disclosure of risk management by the firms (Bravo, 2017; Iswajun et al., 2018). These corporate scandals which affected corporate integrity and investors' confidence in the capital markets worldwide include the Enron, Wordcom and Parmalat as well as Cadbury Plc. scandal in Nigeria which in 2006 recorded an operating loss of N4.665bn well below the previous year's profitability of about N2.7bn. To this end, the management of risks has become an important concern for 
professionals, academia and other stakeholders in the business world as it has potential to increase business output and shareholders' worth (Rudangga et al., 2016).

Substantial number of studies have examined the extent to which risk management disclosure impacted on firm outcomes (Bravo, 2017; Elshandidy et al., 2013; Foerster et al., 2013). In spite of the previous contributions, the empirical evidence linking risk management disclosure with value of firms in Nigeria remains shallow as most of this study focused on developed countries (Bravo, 2017; Carter et al. 2006) with very few studies in Sub-Saharan Africa in particular (Abdullah et al., 2015; Iswajumi et al., 2018). Within the Nigerian context, no study is found to have made this effort to the best of knowledge of the author. This study is thus set out to fill this research gap. Hence, the main objective of this study is to investigate the value relevance of risk management disclosure among listed deposit money banks in Nigeria.

\section{LITERATURE REVIEW}

\section{Risk}

Risk is an indispensable element of any corporate entities particularly banks. Risk disclosure basically entails reporting of risk pertaining to a firm's operations, strategies, and other factors external to the firm that can dampen the expected outcomes (Beretta \& Bozzolan, 2004). Risk disclosure according to Miihkinen (2013) serves as an information describing firms' major risks exposures together with the expected economic impact of such on both their current and future outcomes. Firms take various forms of risks to attain their aims and objectives and a key form of the risks is financial risks (Lombardi et al., 2016).

Financial Risk was classified into three (3) in the financial instrument's disclosures of the International Financial Reporting Standard 7 which are credit, liquidity, and market risk. Market risks are those which arises due to variation in the market price of key items or commodities. For a bank, this risk encompasses foreign exchange and interest rate risk. Credit risk encompasses the risk that that is due to bad debts loss or delays debt settlement by customers. All corporate firms that credit sales to customers are prone to credit risk and this makes banks to be especially prone to this type of risk because of the nature of their operation. Liquidity risk encompasses the risk that exists in a corporate setting when the firm is unable to settle its financial obligations as and when due.

\section{Risk Management}

Risk management is a conscious process that involves the alignment of strategies, processes, technology, people, and know-how or expertise with the aim of assessing, managing, and evaluating the risks faced by any organization (Hoyt \& Liebenberg, 2011). This makes risk management central to strategic decision of any organization. Risk management is thus, the methodological procedure organizations employ to mitigate the risks that are attached to business operations with the purpose of attaining sustainable benefits within 
and across business activities (Vasile et al., 2012). In addition, it is the process of identifying risks that come with firms' operations and constituting means to mitigate such risks by setting the needed controls to maximally limit the likelihood of occurrences and/or mitigate the effects of risks (Vasile et al., 2012).

\section{Firm Value}

Every corporate entity's main objective is arguable the improvement in the welfare of its owner and shareholders. As a result, firms that better improve the welfare of their stakeholders logically attract higher value from the investors. In line with that submission, increased market share prices often reflect improved welfare of the shareholders and owners higher market share prices. Firm value is thus defined as the price willing to be paid by a potential investor or buyer to acquire a unit of the firm share (Jin \& Jorion, 2006).

\section{Theoretical Underpinning}

This study rests on signalling theory. The theory, which is used to analyse participants' behaviour in the labour market characterized with imperfect information was propounded by Spence (1973). In line with the submission of Akerlof (1970), signalling theory suggests that disclosure serves as a signal which mitigates the extent of information asymmetry between the insider and outsiders. This relies on the assumption that an organization that provides accurate risk management information in its annual reports signals the potential to manage the different risk that arises from its activities. According to Spence (1973), nondisclosure of risk or opacity of an enterprise may be misinterpreted by the stakeholders to mean an attempt by management to withhold the worst possible information or the inability to differentiate goods from the bad products that may eventually result in markets meltdown.

This theory has been used in empirical literature to link firm value and corporate disclosure including risk management disclosure (Al-Maghzim et al., 2016). According to Al-Maghzim et al. (2016) for instance, firms signal performance by disclosing relevant information as a way of enhancing their reputation, stock's liquidity, and market valuation. Risk management is thus a form of non-financial information which may serve as a signal to the investors regarding the invested capital security implying that the better and transparent the corporate entity in terms of risk disclosure, the more the confidence of investors in the capital security invested. Thus, investors will be more disposed to buy the share of the firms that signal its risk management through adequate risk management disclosure and the competition for the firm's share drives up the price of the share which eventually leads to higher firm value.

\section{Empirical Review}

Quite a large number of extant literature have studied the link between disclosure practice including risk management disclosure and firm outcome particularly firm value and performance. These studies have 
however produced conflicting results making it difficult to generalize the result obtain in certain setting to another country.

In the league of literature that reported positive and significant impact of risk management disclosure on firm value is Abdullah et al. (2015) who examined the effect of voluntary risk management disclosure on firm value using data from sample of 395 listed firms in Malaysia. The study proxy firm value with market to book value of equity ratio, Tobin $Q$ and market capitalization. The results of the study suggest that voluntary risk management disclosure has significant positive impact on firm value. In the same vein, Iswajuni et al. (2018) studied how enterprise risk management influences the firm value proxied with Tobin's $Q$ using selected listed manufacturing companies on the Indonesian Stock Exchange over the period of 2010 and 2013. The results of the study reveals that enterprise risk management disclosure has significant positive effect on the firm value. Similar result was reported by using a sample of 95 manufacturing companies include in the US standard \& poor's 500 index (Bravo, 2017), and in a sample of listed non-financial firms on Egyptian Stock Exchange (Abdel-Azim \& Abdelmoniem, 2015). Foerster, et al. (2013) also found that disclosure management forecast reduces risk of the firm which then improve firm value in a sample of 4724 firms between 1998 and 2007. Other studies have also established significant positive impact of risk disclosure on firm value (Allayannis \& Weston, 2001; Carter et al., 2006; Graham \& Rogers, 2002).

Another group of studies found that risk management disclosure inversely impacted on the value of firm. For instance, Haj-Salem et al. (2019) investigated how corporate risk disclosure and corporate governance jointly influence firm value using a sample of 156 Tunisian-listed firms for the period covering 2008 to 2013. The study found that corporate risk disclosure has significant negative effect on firm value which was measured using Tobin q.

Aside those studies that reported significant positive and negative impact, others found no significant influence of firms' risk disclosure on their value. Augustina and Baroroh (2016) examined the influence of enterprise risk management on the firm value using a sample of 30 banks listed on the Indonesian Stock Exchange between 2011 and 2013. The results of the study reveal that risk management disclosure has no significant impact on the value of the firm. Similar conclusion was reached in other previous study (Jin \& Jorion, 2006).

Several value relevance studies have recognized the key role of earning per share and book value per share in determining firm value. Some of the studies found significant positive impact of earning per share (Ahmadi et al., 2018; Kamisah \& Rashidah, 2012) and book value per share (Ahmadi et al., 2018) on firm value. On the contrary, some have found negative or no significant impact of earning per share on firm value (Rashidu et al., 2014). 
Previous empirical studies have submitted that certain firm characteristics including firm size, leverage and age of the firm affect firm value. Some of the studied include those that focus on impact of firm size (Iswajuni, et al., 2018; Rudangga et al., 2016; Yuliza, 2018), and leverage (Foerster, et al., 2013).

From the review empirical literature, very few number of studies have been able to examine the impact of risk management disclosure on firm value. The few studies largely focused on the corporate firms operating outside Sub-Saharan Africa and Nigeria in particular. In addition, the studies have yet to reach consensus as to the direction of relationship between risk management disclosure and firm value as they produced conflicting results. While some of the studies reported positive impact, some reported negative impact while another set of studies reported no significant impact. The implication of these is that the link between risk management disclosure and firm value is still much open to empirical research. Hence, this study fills the gap by examining the value relevance of risk management disclosure among listed deposit money banks in Nigeria.

\section{METHODOLOGY}

\section{Data and Technique of Analysis}

The data used in this study were manually extracted from the annual reports of 10 listed deposit money banks between 2014 and 2018 using content analysis. The population of the study consist of twenty listed deposit money banks out of which the 10 banks that consistently published their annual reports for the period are selected as sample. By implication, the study used judgmental sampling to select the data from ten banks. The selection of 10 out of the 20 money deposit banks is due to data limitations as only the ten consistently publish full annual reports for the period considered.

The study was analysed using both descriptive and inferential statistical tool of panel regression. While descriptive statistics tools of mean, standard deviation together with correlation analysis were utilized for preliminary analysis, the panel regression was used to investigate the extent to which risk management disclosure influence the firm's value while holding other variables constant. The three basic panel model forms including Fixed Effects, pooled OLS and random effects were estimated and the best one was selected using two different specification tests including the F-test and Hausman test. The data of the study were analysed using STATA 14.0 statistical software.

\section{Model Specification}

The model specification for this study relies mainly on the Ohlson (1995) model of firm value, the theoretical framework of the study and the reviewed empirical literature. According to Ohlson (1995) model, market value of the firm depends on the book value per share and earning per share while the 
theoretical framework of the study suggests that risk management disclosure impact significantly on the firm value. Also, the reviewed empirical literature suggest that the share price of the firm is affected by firm characteristics such as firm age, size and financial leverage. Accordingly, the model for this study is specified as:

$S P=f(E P S, B V P S, R M D, F s i z$, Lev, lage $) \quad-\quad-\quad-$

Where:

$\mathrm{SP}$ is the stock price

EPS is earning per share

BVPS is the book value per share

RMD represents risk management disclosure

Fsiz stands for firm size

Lev is financial leverage

lage is the natural log of age

(1) could be represented in linear econometric form as

$$
\begin{aligned}
& \quad S P_{i t}=\tau+\vartheta E P S_{i t}+\varphi B V P S_{i t}+\omega R M D_{i t}+\sigma F s i z_{i t}+\lambda L_{L v} v_{i t}+\eta l a g e_{i t}+ \\
& \mu_{i t}---(2)
\end{aligned}
$$

Where:

$$
\varepsilon_{i t}=\rho_{i}+\varepsilon_{i t} \quad-\quad-\quad-\quad-(3)
$$

If (3) is not true, then (3) could be estimated using OLS (Pooled OLS). If it is however true, OLS cannot be used and (2) becomes

$$
S P_{i t}=\tau+\vartheta E P S_{i t}+\varphi B V P S_{i t}+\omega R M D_{i t}+\sigma F s i z_{i t}+\lambda L e v_{i t}+\eta l a g e_{i t}+\rho_{i}+\varepsilon_{i t}
$$

\section{Measurement of Variables}

The dependent variable of this study is firm value. The study follows previous value relevance studies (Kusiyah \& Arief, 2017) by measuring the firm value using share price of the individual firm at the close of financial year.

The study has six independent variables including EPS, BVPS, RMD, Fsiz, Lev and lage. RMD is measured using disclosure index in line with previous empirical work on risk management disclosure. In particular the framework which is made up of disclosure were formed based on grid risk report as used in Dey et al. (2018) where sections of annual reports and notes to the financial statements which cover information on risks or uncertainties were examined. In the modified grid report used by Dey et al. (2018) 
and followed in this study, the financial risk is categorized into six including capital structure risk which has six identifiers, credit risks with seven identifier, liquidity risks with six identifiers, currency risks with four identifiers, and interest rate risks with four identifiers and general risk with three identifiers (see appendix). Those 30 identifiers were scored using a dichotomous approach. In line with dichotomous approach, an identifier scores ' 1 ' if reported and Zero ' 0 ' if not reported. This means that all identifiers of risk management were given equal importance and what is considered is only whether an identifier is reported or otherwise in its annual report. The formula for calculating the un-weighted reporting scores is expressed as:

$R M D=\sum_{i=1}^{30} d_{i} / d \quad 0 \leq \mathrm{RMD} \leq 1$

Where:

$\mathrm{RMD}$ is risk management disclosure index.

$d=1$ if item 'di' is reported or 0 if item ' $d i$ ' is not reported

$d=$ maximum obtainable items ( 30 in this case)

The value of RMD is the ratio of the value of computed total disclosures score obtained by each firm to the maximum number obtainable points.

The summary description of variables of the study as well as their respective source is presented in Table 1.

TABLE 1. VARIABLES DEFINITION AND SOURCES

\begin{tabular}{|l|l|l|}
\hline Variables & Description & Source \\
\hline Firm's value (SP) & $\begin{array}{l}\text { Financial year closing stock } \\
\text { price }\end{array}$ & Kusiyah \& Arief (2017) \\
\hline $\begin{array}{l}\text { Risk management } \\
\text { Disclosure }\end{array}$ & $\begin{array}{l}\text { Credit risk, liquidity risk, Interest } \\
\text { rate risk, currency risk, capital } \\
\text { structure risk, and general risk }\end{array}$ & Dey et al. (2018) \\
\hline Earnings per share (EPS) & $\begin{array}{l}\text { This is earning per share } \\
\text { measured as profit after share } \\
\text { as a ratio of the outstanding } \\
\text { shares }\end{array}$ & Ahmadi et al. (2018) \\
\hline Book value per share (BVPS) & $\begin{array}{l}\text { This is measured as the } \\
\text { difference between total assets } \\
\text { and total liabilities as a ratio of } \\
\text { outstanding shares }\end{array}$ & Iswajuni et al. (2019) \\
\hline
\end{tabular}


Olowookere, J. K. \& Feruke, B. R.

VALUE RELEVANCE OF RISK MANAGEMENT DISCLOSURE AMONG LISTED DEPOSIT MONEY BANKS IN NIGERIA

\begin{tabular}{|l|l|l|}
\hline Firm size (Fsiz) & $\begin{array}{l}\text { Natural log of total assets of the } \\
\text { firm }\end{array}$ & Ahmadi et al. (2018) \\
\hline Leverage (Lev) & $\begin{array}{l}\text { This is measured as long term } \\
\text { debt as ratio of total equities }\end{array}$ & Foerster (2013) \\
\hline Age (lage) & $\begin{array}{l}\text { This measured as log of the } \\
\text { years a bank has been listed on } \\
\text { the NSE }\end{array}$ & Pervan et al. (2017) \\
\hline
\end{tabular}

Source: Authors' Compilation (2020)

\section{RESULTS AND DISCUSSION}

\section{Descriptive Analysis}

The summary statistics of the variables of the study are presented in Table 2. The results indicate that the average share price of the firms within the period is 10.79 naira with minimum share price of 0.52 and maximum price of 49.15 naira. The standard deviation of 12.068 reveal a large variation in the share price of the listed banks for the period considered in this study. The results further reveal that the average earning per share is 2.066 naira with minimum and maximum share price of 0.058 and 7.04 respectively. Its corresponding standard deviation of 1.905 show considerably high variation in the earning per share of the company for the period. In addition, the results reveal that the average book value per share is 11.191 with standard deviation of 7.24 , minimum of 1.14 and maximum of 26.1 naira. It was revealed from the results that the average risk management disclosure is 0.727 with minimum of 0.167 and maximum of 1 . The standard deviation of 0.187 for risk management disclosure implies that no wide variation in the risk management disclosure practices of the banks.

Furthermore, the results reveal that the average log of age is 3.099 with minimum of 2.197 and maximum of 3.871 and standard deviation of 0.545 . Also, the estimated average leverage is 0.748 with minimum of 0.25 and maximum leverage of 2.163 and standard deviation of 0.399 . The estimated average firm size is 21.345 with minimum value of 19.762 and maximum of 22.508 .

TABLE 2. SUMMARY STATISTICS

\begin{tabular}{|l|r|r|r|r|r|}
\hline Variable & Obs & Mean & Std.Dev. & Min & Max \\
\hline SP & 50 & 10.794 & 12.068 & .52 & 49.15 \\
\hline EPS & 50 & 2.066 & 1.905 & .058 & 7.04 \\
\hline BVPS & 50 & 11.191 & 7.24 & 1.14 & 26.1 \\
\hline RMD & 50 & .727 & .187 & .167 & 1 \\
\hline
\end{tabular}


Olowookere, J. K. \& Feruke, B. R.

VALUE RELEVANCE OF RISK MANAGEMENT DISCLOSURE AMONG LISTED DEPOSIT MONEY BANKS IN NIGERIA

\begin{tabular}{|l|r|r|r|r|r|}
\hline lage & 50 & 3.099 & .545 & 2.197 & 3.871 \\
\hline Lev & 50 & .748 & .399 & .25 & 2.163 \\
\hline Fsiz & 50 & 21.345 & .804 & 19.762 & 22.508 \\
\hline
\end{tabular}

Source: Authors' Computation (2020)

The results of the correlation analysis are presented in Table 3. The results revealed that share price is highly positive correlated with the earning per share indicating that share price increases with earning per share. Book value per share also has high positive relationship with share price given its estimated correlation coefficient of 0.687 . Both risk management disclosure and firm size have weak positive relationship with share price while log of age of the firm and leverage have weak relationship with the share price. The estimated correlation coefficients among the explanatory variables reveal that the variables are not highly correlated as the highest estimated coefficient of 0.704 between BVPS and EPS is not up to the threshold of 0.9 for multicollinearity to exist among the regressors.

TABLE 3. MATRIX OF CORRELATIONS

\begin{tabular}{|c|c|c|c|c|c|c|c|}
\hline Variables & (1) & (2) & (3) & (4) & (5) & (6) & (7) \\
\hline (1) SP & 1.000 & & & & & & \\
\hline (2) EPS & 0.888 & 1.000 & & & & & \\
\hline (3) BVPS & 0.687 & 0.704 & 1.000 & & & & \\
\hline (4) RMD & 0.361 & 0.230 & 0.346 & 1.000 & & & \\
\hline (5) lage & -0.348 & -0.352 & -0.068 & -0.171 & 1.000 & & \\
\hline (6) Lev & -0.362 & -0.407 & -0.493 & -0.278 & 0.148 & 1.000 & \\
\hline (7) Fsiz & 0.318 & 0.553 & 0.603 & -0.057 & 0.141 & -0.414 & 1.000 \\
\hline
\end{tabular}

\section{Diagnostic test}

The variance inflation factor results presented in Table 4 indicate that BVPS and EPS have VIF of 2.836 and 2.82 respectively while risk management disclosure has VIF of 1.364. Firm size, log of age and leverage have VIF of 2.289, 1.472 and 1.462 respectively while the mean VIF is estimated to be 2.04 . Since the highest estimated VIF is short of the threshold of 10 , the problem of multicolinearity cannot be established among the regressors. 
Olowookere, J. K. \& Feruke, B. R.

VALUE RELEVANCE OF RISK MANAGEMENT DISCLOSURE AMONG LISTED DEPOSIT MONEY BANKS IN NIGERIA

TABLE 4. ESTIMATED VARIANCE INFLATION FACTOR

\begin{tabular}{|l|r|r|}
\hline & VIF & $1 / \mathrm{VIF}$ \\
\hline BVPS & 2.836 & .353 \\
\hline EPS & 2.82 & .355 \\
\hline Fsiz & 2.289 & .437 \\
\hline Lage & 1.472 & .68 \\
\hline Lev & 1.462 & .684 \\
\hline RMD & 1.364 & .733 \\
\hline Mean VIF & 2.04 &. \\
\hline
\end{tabular}

Source: Authors' Computation (2020)

Table 5 contains other diagnostic test results. From the results, the F-test for the presence of firm effect with $p$ value of 0.0040 implies that the model is characterized with the presence of firm effect. The implication of the result of the F-test is that POLS would not bring a consistent result as the assumption of endogeneity is violated. Results of the Hausman test conducted show an estimated Hausman $p$ value of 0.6312 which indicates that the null hypothesis that random effect is appropriate cannot be rejected at all conventional significant level. Thus, the interpretation of the results in this study is based on the results of the random effect presented in the last column of Table 6.

In addition, the study investigated if the results are free from the problem of serial correlation and heteroskedasticity by conducting Wooldridge test for serial correlation and Breusch-Goldfrey test for heteroskedasticity. The results of the Wooldridge test with $p$ value of 0.7887 shows that the results in Table 6 is free of serial correlation as the null hypothesis of no serial correlation could not be rejected. The results of the heteroskedasticity test with $p$ value of 0.0000 indicate that the null hypothesis of homoscedasticity is rejected which implies that the model is characterised with heteroskedasticity. The problem is corrected by obtaining the results in Table 6 with robust (heteroskedasticity autocorrelation consistent) standard error. The results of the Ramsey RESET test with p-value of 0.2239 Indicates that the null hypothesis of no specification error could not be rejected implying that the model in the study is well specified.

TABLE 5. REGRESSION DIAGNOSTIC TESTS

\begin{tabular}{|l|l|l|l|}
\hline Test & Type & P value & Conclusion \\
\hline Firm Effect & F-test & 0.0040 & Firm effect present \\
\hline Systematic Difference & Hausman & 0.6312 & Random effect performs better \\
\hline Omitted Variables & Ramsey RESET & 0.2239 & No specification error \\
\hline Heteroskedasticity & $\begin{array}{l}\text { Breusch-Pagan/Cook- } \\
\text { Weisberg }\end{array}$ & 0.000 & There is heteroskedasticity \\
\hline
\end{tabular}


Olowookere, J. K. \& Feruke, B. R.

VALUE RELEVANCE OF RISK MANAGEMENT DISCLOSURE AMONG LISTED DEPOSIT MONEY BANKS IN NIGERIA

\begin{tabular}{|l|l|l|l|}
\hline Autocorrelation & Wooldridge Test & 0.7887 & No autocorrelation \\
\hline
\end{tabular}

Source: Authors' Computation (2020)

\section{Panel Regression Results}

The estimated coefficient of 4.336 with corresponding $p$ value of 0.0469 indicates that risk management disclosure has positive influence which is significant at 5 percent level of significance on the share price of listed deposit money banks in Nigeria. By implication, the deposit money banks that disclose more risk management practice of the company attract more prospective investors who then help to bid up the share price of the firms. Thus, the disclosure of risk management by listed Nigeria deposit money banks is value relevant. The finding of this study on risk management disclosure aligns with the signalling theory and the results of the previous empirical literature that reported positive and significant impact of risk management disclosure on share price (Bravo, 2017; Iswajuni et al., 2018).

TABLE 6. ESTIMATED PANEL REGRESSION RESULTS

\begin{tabular}{|c|c|c|c|}
\hline & (1) & (2) & (3) \\
\hline VARIABLES & POLS & $\mathrm{FE}$ & $\mathrm{RE}$ \\
\hline \multirow[t]{2}{*}{ EPS } & $5.788^{* \star *}$ & $4.093^{\star * \star}$ & $4.925^{\star * *}$ \\
\hline & $(7.41 \mathrm{e}-10)$ & $(0.00260)$ & $(1.75 \mathrm{e}-09)$ \\
\hline \multirow[t]{2}{*}{ BVPS } & $0.364^{* *}$ & 0.470 & 0.383 \\
\hline & $(0.0144)$ & $(0.309)$ & $(0.115)$ \\
\hline \multirow[t]{2}{*}{ ENPD } & $4.058^{* *}$ & $3.983^{*}$ & $4.336^{* *}$ \\
\hline & $(0.0427)$ & $(0.0586)$ & $(0.0469)$ \\
\hline \multirow[t]{2}{*}{ Lage } & 1.034 & -13.00 & -0.445 \\
\hline & $(0.450)$ & $(0.277)$ & (0.696) \\
\hline \multirow[t]{2}{*}{ Lev } & -0.205 & -2.833 & -0.647 \\
\hline & $\begin{array}{l}(0.854) \\
\end{array}$ & $(0.263)$ & $(0.550)$ \\
\hline \multirow[t]{2}{*}{ Fsiz } & $-4.876^{* * *}$ & 6.927 & $-3.006^{*}$ \\
\hline & $(0.000106)$ & $(0.127)$ & $(0.0501)$ \\
\hline Constant & $92.84^{* \star *}$ & -111.3 & $59.20^{*}$ \\
\hline
\end{tabular}


Olowookere, J. K. \& Feruke, B. R.

VALUE RELEVANCE OF RISK MANAGEMENT DISCLOSURE AMONG LISTED DEPOSIT MONEY BANKS IN NIGERIA

\begin{tabular}{|l|c|c|c|}
\hline & $(9.82 \mathrm{e}-05)$ & $(0.105)$ & $(0.0621)$ \\
\hline Observations & 50 & 50 & 50 \\
\hline R-squared & 0.867 & 0.715 & \\
\hline Number of ID & & 10 & 10 \\
\hline
\end{tabular}

Robust $p$-value in parentheses: ${ }^{* * *} p<0.01,{ }^{* *} p<0.05,{ }^{*} p<0.1$

Source: Authors' Computation (2020)

The estimated random effect panel regression results in Table 6 show in estimated coefficient of 4.925 and corresponding $p$ value of 0.000 for earning per share. This implies that earning per share has positive impact, which is significant at 1 percent level of significance, on the share price of the sampled banks. The implication of the results is that earning per share drives the value of the listed deposit money banks in Nigeria. The finding on EPS aligns with the Ohlson (1995) framework and the previous empirical findings who reported significant positive impact of EPS on firm share price (Ahmadi et al., 2018; Kamisha \& Rashidah, 2012). The estimated coefficient of 0.383 with corresponding $p$ value of 0.115 indicates that book value per share has no significant impact on the share price of quoted Nigerian deposit money banks. The implication of the result is that prospective investors do not attach significant value to the BVPS in making their investment decision. This finding failed to agree with the Ohlson (1995) framework and previous empirical literature that have reported significant positive impact of book value per share on the share price of listed in Nigeria (Ahmadi et al., 2018).

For other control variables, the results indicate that log of age has negative but insignificant impact on the share price of the firms. The implication is that whether the firm is new or old does not influence the share price of the listed banks in Nigeria. This may be due to the fact that virtually all the banks that make up the sample have been in existence for more than a decade and as such, they are equally well known to the prospective investors. The estimated coefficient of -3.006 with corresponding $p$ value of 0.0501 indicate that firm size has significant negative impact on the share price of the firm. By implication, smaller banks attract higher share price than the bigger firms. This finding contradicts the submission of previous empirical literature that firm size exerts positive and significant influence on the share price of firms (Iswaju et al., 2018; Yuliza, 2018). It however aligns with the finding of Foerster et al., (2013).

\section{CONCLUSION AND RECOMMENDATIONS}


This study examines the value relevance of Nigerian quoted deposit money banks. The results suggest that the disclosure of risk management is value relevant in Nigeria as investors consider the extent to which the banks declare their potential risk and how they are to manage them before making their investment decision. Thus, companies need to understand that improvement in the disclosure of risk management is as important as improving the company's value. In addition, the results of this study reveal an important role of earning per share on the share price of the firms sampled. Based on the results, this study recommends that managers of the deposit money bank in the country should pay attention to the disclosure of risk management in their annual report to enhance the development of their company's share price which will in turn increase the value of the company.

\section{REFERENCES}

Abdel-Azim, M.H., \& Abdelmoniem, Z. (2015). Risk management and disclosure and their impact on firm value: The case of Egypt. International Journal of Business, Accounting and Finance, 9 (1): 1-14.

Abdullah, M., Shukor, Z.A., Muhammed, Z.M., \& Ahmad, A. (2015). Risk management disclosure: A study on the effect of voluntary risk management disclosure toward firm value. Journal of Applied Accounting Research, 16 (3): 400-432.

Ahmadi, A., Garraoui, M., \& Bouri, A. (2018). The value relevance of book value, earnings per share and cash flow: Evidence of Tunisian banks and financial institutions. International Academic Journal of Accounting and Financial Management, 5(1): 47-56.

Akerlof, G. (1970). The market for 'lemons': Quality uncertainty and the market mechanism. Quarterly Journal of Economics, 90(4): 629-650.

Allayannis, G., \& Weston, J. (2001). The use of foreign currency derivatives and firm market value. Review of Financial Studies, 14: 243-276.

Augustina, L. \& Baroroh, N. (2016). The relationship between enterprise risk management (ERM) and firm value mediated through the financial performance. Review of Integrative Business and Economics Research, 5(1): 128-138,

Beretta, S. E., \& Bozzolan, S. (2004). A framework for the analysis of firm risk communication. The International Journal of Accounting, 39 (3): 265 - 288.

Bravo, F. (2017). Are risk disclosures an effective tool to increase firm value? Managerial and Decision Economics, 38(8): 1116-1124.

Bushman, R. M. (2016). Transparency, accounting discretion, and bank stability. Economic Policy Review, 22(1): 129-149.

Carter, D.A., Rogers, D.A., \& Simkins, B.J., (2006). Does hedging affect firm value? Evidence from the US airline industry. Financial Management, 35: 53-86.

Dey, R.K., Hossain, S.Z., \& Rezaee, Z. (2018). Financial risk disclosure and financial attributes among publicly traded manufacturing companies: Evidence from Bangladesh. Journal of Risk and Financial Management, 11(50): 1-16. 
Duru, A., Hasan, I., Song, L., \& Zhao, Y. (2018). Bank accounting regulations, enforcement mechanisms and financial statement informativeness: Cross-country evidence. Accounting and Business Research, 50 (3): 269-304.

Elshandidy T. (2014) Value relevance of accounting information: Evidence from an emerging market. Advances in Accounting, 30(1): 176-186.

Elshandidy, T., Fraser, I. \& Hussainey, K. (2013). Aggregated, voluntary, and mandatory risk disclosure incentives: Evidence from UK FTSE all-share companies. International Review of Financial Analysis, 30(2013): 320-333.

Fadun, O. S. (2013). Risk management and risk management failure: Lessons for business enterprises. International Journal of Academic Research in Business and Social Sciences, 3(2): 225.

Foerster, S. R., Sapp, S.G., \& Shi, Y. (2013, Jan 12). The Effect of Voluntary Disclosure on Firm Risk and Firm Value: Evidence from Management Earnings Forecasts. CAAA Annual Conference.

Giner, B., \& Mora, A. (2019). Bank loan loss accounting and its contracting effects: The new expected loss models. Accounting and Business Research, 49(6): 726-752.

Graham, J., \& Rogers, D. (2002). Do firms hedge in response to tax incentives? Journal of Finance, 57: 815-839.

Haj-Salem, I., Ayadi, S.D., \& Hussainey, K. (2019). The joint effect of corporate risk disclosure and corporate governance on firm value. International Journal of Disclosure and Governance, https://doi.org/10.1057/s41310-020-00079-w

Hoyt, R.E. \& Liebenberg, A.P. (2011). "The value of enterprise risk management". Journal of Risk and Insurance, 78(4): 795-822.

Iswajuni, I., Manasikana, A., \& Soetedjo, S. (2018). The effect of enterprise risk management (ERM) on firm value in manufacturing companies listed on Indonesian Stock Exchange year 2010-2013. Asian Journal of Accounting Research, 3(2): 224-235.

Jin, Y., \& Jorion, P. (2006). Firm value and hedging: Evidence from U.S. oil and gas producers. The Journal of Finance, 61: 893-919.

Kamisah, I. \& Rashidah, A. (2012). The wealth of information from quarterly financial reports in Malaysia. African Journal of Business Management, 6(3): 1054-1067.

Kusiya, U. \& Arif, M. (2017). The determinants of firm value on commercial banks in Indonesia. Journal of Engineering and Applied Sciences, 12: 408-416

Lombardi, R., Coluccia, D., Russo, G. \& Solimene, S. (2016). Exploring financial risks from corporate disclosure: Evidence from Italian listed companies. Journal of the Knowledge Economy, 7: 30927.

Miihkinen, A. (2013). The usefulness of firm risk disclosures under different firm riskiness, investorinterest, and market conditions: new evidence from Finland. Advances in Accounting, $\quad$ 29(2): 312-331.

Nier, E. W. (2005). Bank stability and transparency. Journal of Financial Stability, 1(3): 342-354.

Ohlson, J. A. (1995). Earnings, book values, and dividends in equity valuation. Contemporary Accounting Research, 11(2): 661-687.

Pervan, M., Pervan, I., \& Curak, M. (2017). The influence of age on firm performance: Evidence from the Croatian food industry. Journal of Eastern Europe Research in Business and Economics, 1-10

Rashidul, I., Khan, R, Choudhury, T.T. \& Adnan, A.M. (2014). How earning per share (EPS) affects share price and firm value. European Journal of Business and Management, 5(17): 97-108. 
Rudangga, I. Gede, G.G. \& Merta, S.G. (2016). The effect of company size, leverage, and profitability on company value. E-Journal of Management Unud, 5(7): 4394 - 4422.

Shortreed, J., Hicks, J., \& Craige, L. (2003). Basic frameworks for risk management. Ontario: Network for Environmental Risk Assessment and Management.

Solomon, J.F., Solomon, A., Norton, S.D. \& Joseph, N.L. (2000). A conceptual framework for corporate risk disclosure emerging from the agenda for corporate governance reform. The British Accounting Review, 32(4): 447-478.

Spence, M. (1973). Job market signalling. The Quarterly Journal of Economics, 87(3): 355- 374.

Vasile, E., Croitoru, I., \& Mitran, D. (2012). Risk management in the financial and accounting activity. Internal auditing and risk management annul, 1(25): 13-24. 